Published in final edited form as:

Endocrine. 2013 February ; 43(1): 12-21. doi:10.1007/s12020-012-9751-7.

\title{
Atrogin-1, MuRF-1, and sarcopenia
}

Jonathan P. Gumucio and Christopher L. Mendias

Departments of Orthopaedic Surgery and Molecular \& Integrative Physiology, University of Michigan Medical School, 109 Zina Pitcher Place, BSRB 2017, Ann Arbor, MI 48109-2200, USA

\begin{abstract}
Sarcopenia is one of the leading causes of disability in the elderly. Despite the growing prevalence of sarcopenia, the molecular mechanisms that control aging-related changes in muscle mass are not fully understood. The ubiquitin proteasome system is one of the major pathways that regulate muscle protein degradation, and this system plays a central role in controlling muscle size. Atrogin-1 and MuRF-1 are two E3 ubiquitin ligases that are important regulators of ubiquitinmediated protein degradation in skeletal muscle. In this review, we will discuss: (i) aging-related changes to skeletal muscle structure and function; (ii) the regulation of protein synthesis and protein degradation by IGF-1, TGF- $\beta$, and myostatin, with emphasis on the control of atrogin-1 and MuRF-1 expression; and (iii) the potential for modulating atrogin- 1 and MuRF-1 expression to treat or prevent sarcopenia.
\end{abstract}

\section{Keywords}

Atrogin-1; IGF-1; MuRF-1; Myostatin; Sarcopenia; TGF- $\beta$

\section{Introduction}

Sarcopenia is broadly defined as the loss of skeletal muscle mass and function that occurs with aging [1]. As muscle mass decreases, there is an accompanying loss in strength, aerobic capacity, and metabolic rate that contribute to the reduced function and quality of life that patients with sarcopenia endure [2]. Preventing and treating sarcopenia can be challenging, but many recent studies have provided important insight into the cellular and molecular etiology of aging-associated decreases in muscle mass, and these findings may be quite useful in the development of new therapies to prevent and treat sarcopenia. This review will provide an overview of the diagnosis and epidemiology of sarcopenia, discuss the role of atrogin-1, MuRF-1, and the E3 ubiquitin ligase system in the aging-related loss of muscle mass, and describe therapeutic interventions for the prevention and treatment of sarcopenia.

While the original definition of sarcopenia encompassed all elderly individuals, there is considerable variation in the amount of muscle that is lost as an individual ages [3]. Since the original definition was proposed, there has been much interest in developing a set of guidelines for the diagnosis of sarcopenia to differentiate the normal physiological loss in muscle mass that occurs with aging from a pathological loss. In 2009, the International Working Group on Sarcopenia, composed of leading physicians and scientists from academia and industry, developed a consensus definition for the diagnosis of sarcopenia and

(C) Springer Science+Business Media, LLC 2012

Correspondence to: Christopher L. Mendias.

cmendias@umich.edu.

The authors declare they have no conflict of interest. 
screening guidelines to identify patients with sarcopenia [2]. The guidelines recommend a two-part evaluation based on the patient's history and overall health status, followed by a test for physical function. Patients who screen positive for the potential of sarcopenia should then have a whole body dual energy X-ray absorptiometry (DXA) scan performed for a definitive diagnosis. The screening based upon history includes patients with: (i) a history of recurrent falls; (ii) recent unintentional weight loss of greater than $5 \%$ of overall body mass; (iii) difficulty performing activities of daily living; (iv) a recent hospital stay; (v) the inability to leave their bed; (vi) the inability to rise from a chair unassisted; and (vii) chronic conditions associated with muscle loss, including type 2 diabetes, chronic heart failure, chronic obstructive pulmonary disease, rheumatoid arthritis, and malignancies. For at-risk patients who can arise from a chair, gait speed should be measured across a $4 \mathrm{~m}$ course. Patients who have a gate speed less than $1 \mathrm{~m} / \mathrm{s}$ should then be further screened using a DXA scan. Based on results from the DXA scans, a diagnosis of sarcopenia can be confirmed if appendicular lean mass is less than the 20th percentile of values for young adults, or 7.23 $\mathrm{kg} / \mathrm{m}^{2}$ for men and $5.67 \mathrm{~kg} / \mathrm{m}^{2}$ for women. In addition to these guidelines, a recently developed patient-reported outcome tool may also be of use in identifying and tracking the status of patients with sarcopenia [4].

Individuals with sarcopenia often have markedly greater rates of physical disability and reduced capacity to perform activities of daily living [3]. Sarcopenia can not only have a dramatic impact on the quality of life of an individual but also imposes a significant burden to public health systems. In the US in 2000, the estimated direct healthcare cost attributable to sarcopenia was $\$ 18.5$ billion, which represented approximately $1.5 \%$ of total healthcare expenditures for that year [5]. It is estimated that between 5 and $13 \%$ of adults aged 60-70, and $11-50 \%$ of the population aged 80 and over, suffer from sarcopenia [6]. With estimates from the World Health Organization that the amount of adults aged over 60 will continue to increase tremendously over time, it is likely that there will be a concomitant increase in the rates of sarcopenia [3]. Developing new therapies for the prevention and treatment of sarcopenia not only will help to improve the quality of life for patients who suffer from this disease, but also will help to reduce the economic and productivity burdens for society in general.

\section{Aging-related changes in muscle structure and function}

The aging-related decline in skeletal muscle size and function is a well-documented phenomenon. The number of fibers in a muscle and the size of the fibers remain relatively stable from puberty until the fifth decade of life, at which point a noticeable decline in muscle fiber number and size begins [7-9]. At the whole muscle level, there is a reduction in force and a decrease in the number of motor units $[10,11]$. The aging-related decline in fiber size and number impacts fast-twitch type II muscle fibers to a greater extent than slowtwitch type I muscle fibers [11-13]. In terms of force production, compared with muscle fibers from young subjects, type II fibers of old subjects have a smaller cross-sectional area (CSA) and generated less total force, although the specific force (force normalized to CSA of the fiber) is not different $[11,12]$. Interestingly, for type I fibers, there is actually a slight aging-associated increase in fiber CSA and force production, but no change in specific force $[11,12]$. The combination of a decrease in type II muscle fiber number, area, and total force production suggest that much of the aging-related decrease in whole muscle strength is due to a decrease in type II muscle fibers. These findings are also illustrated quite well in terms of athletic performance by comparing world records for sporting events that utilize primarily type I fibers, such as endurance running, with events that utilize primarily type II fibers, such as weightlifting. For elite marathon runners, by the time they are in their 80 s they can still run times that are only $40 \%$ slower than their best time in their youth, while elite weight lifters are typically $60 \%$ weaker than they were in their youth [7]. 
Skeletal muscle fibers are multinucleated cells, and the size of muscle fibers is dependent to some extent on the number of nuclei present within a fiber [14]. While nuclei within fibers are capable of undergoing apoptosis during times of disuse or injury, they are unable to replicate [14]. The new nuclei added to muscle fibers after periods of injury or inactivity come from a population of resident stem cells referred to as satellite cells. Satellite cells normally exist in a quiescent state between the basal lamina and the fiber plasma membrane, and following injury or exercise, satellite cells become activated, migrate to the site of injury, proliferate, and fuse to regenerate the fiber by providing an additional source of nuclei [15]. A certain number of satellite cells will return to quiescence and resume their normal position around the fiber. There is an aging-related decline in the density and regenerative capacity of satellite cells [16,17], although this appears to be due to systemic changes in the environment of the organism rather than inherent changes in satellite cells themselves [18-20]. This decrease in the regenerative capacity of satellite cells can prolong the recovery of muscle to eccentric injury, and overtime likely contribute to the slow, progressive loss in muscle mass that occurs with sarcopenia.

Mitochondria are organelles within muscle fibers that play an important role in metabolism and regulating nuclear apoptosis. There is an aging-related decline in the biogenesis of mitochondria [21], as well as the turnover of damaged mitochondria [22]. Mitochondria also appear to play a role in contributing to aging-related increases in apoptotic signaling [23]. Despite these findings, a direct connection between muscle fiber nuclear apoptosis and sarcopenia has yet to be firmly determined [24]. This decrease in mitochondrial biogenesis and function likely contributes to overall reduced aerobic capacity and endurance seen in patients with sarcopenia.

\section{Molecular pathways regulating skeletal muscle growth and atrophy}

Maintaining muscle mass is a balance between protein synthesis and protein degradation systems. An increase in muscle mass can come about due to either an increase in protein synthesis or a decrease in degradation, while a decrease in muscle mass can occur as a result of decreasing protein synthesis or increasing protein degradation. An overview of the signaling pathways discussed in this review is shown in Fig. 1.

\section{Skeletal muscle hypertrophy}

One of the most widely studied activators of muscle hypertrophy is IGF-1. Compared with wild-type controls, transgenic mice that overexpress IGF-1 under the control of musclespecific promoters has increased muscle mass, CSA, and maximum isometric force [25]. In addition, mice with a muscle-specific loss of IGF-1 receptor have reduced whole body and muscle mass, and decreased fiber quantity and CSA [26]. Binding of IGF-1 to its receptor activates insulin receptor substrate-1, IRS-1, which then activates phosphatidylinositol-3kinase (PI3K), responsible for the conversion of intramembranous phosphoinositide-(4,5)biphosphate (PIP2) to phosphoinositide-(3,4,5)-triphosphate (PIP3) [27, 28]. IGF-1 receptor mediated activation of protein synthesis is PI3K dependent [29]. The serine/threonine kinase Akt (protein kinase B), binds PIP3 on the membrane through an N-terminal pleckstrin homology (PH) domain and is activated by phosphoinositide-dependent kinase-1 (PDK1). The recruitment of Akt to the membrane and the activation of Akt through PDK1 allow Akt to be released into cytosol to activate mTOR and other downstream effectors [28, 30, 31]. In addition to IGF-1, there are also alternative spliced isoforms of IGF-1 that appear to have various roles in regulating skeletal muscle growth. While covering the various IGF-1 isoforms is beyond the scope of this review, we recommend other reviews that discuss this topic in depth [32-34]. 
mTOR is considered one of the most critical regulators of skeletal muscle mass [35-37]. While IGF-1 activates mTOR through Akt, the alternately spliced, locally expressed isoform of IGF-1, IGF-1Ea, appears to activate mTOR independent of Akt [34, 38]. Under special conditions, mTOR can also signal upstream to further activate Akt [39]. Akt acts on mTOR by TSC1 and TSC2, which through the inhibition of the small G protein Rheb, increases mTOR activity $[29,40]$. mTOR signals downstream through the activation of p70S6K, which increases protein synthesis by activating S6 and eIF4B, factors that increase mRNA translation and ribosomal biogenesis [41, 42]. Phosphorylation of 4EBP1 by mTOR releases its inhibition on eIF4E, allowing translation to proceed [42, 43]. Inhibiting mTOR activity is an effective way to curb protein synthesis, as mTOR is inhibited by the drug rapamycin, which can halt load-induced muscle growth [35, 44, 45]. Other endogenous factors can decrease Akt/mTOR signaling to prevent protein synthesis and also promote protein degradation, which are reviewed in detail in other publications [37, 46].

\section{Skeletal muscle atrophy}

Muscle atrophy is a tightly controlled process that involves many signaling pathways and effector proteins, including some cross-talk with the protein synthesis pathway. There are several pathways that control muscle protein degradation, but this review will focus on the ubiquitin proteasome pathway and its control by two potent muscle atrophy-inducing cytokines, myostatin, and TGF- $\beta$. Nuclear apoptosis is another important contributing factor to aging-related muscle atrophy, and while it is beyond the scope of this review, we suggest other excellent publications which discuss this topic in depth [47, 48].

Myostatin is a member of the TGF- $\beta$ superfamily of cytokines, and mice that are deficient in myostatin have an up to twofold increase in skeletal muscle mass [49]. Adult myostatindeficient mice also have greater maximum isometric force production in many muscle groups compared with their wild-type counterparts [50,51]. While blocking myostatin leads to muscle growth, systemic administration of myostatin induces profound cachexia [52]. TGF- $\beta$ is also a potent inducer of muscle atrophy, with local administration of TGF- $\beta$ leading to marked muscle atrophy and reductions in force production [53].

Both myostatin and TGF- $\beta$ are held in an inactive form in the muscle extracellular matrix, and when activated, bind to their receptors and activate the Smad2/3 and TAK1/p38 MAPK signal transduction cascades [54-60]. Myostatin preferentially binds to the type IIB and type IB activin receptors, while TGF- $\beta$ signals through the TGF- $\beta$ type II and type I receptors [61]. Smad2 and Smad3 are transcription factors that bind DNA and directly regulate the expression of target genes [58]. Smad2/3 can also bind members of the FoxO family of transcription factors to regulate gene expression [62, 63]. p38 MAPK is activated by TAK1 downstream of the activin and TGF- $\beta$ receptors, and while p38 MAPK does not directly bind DNA it can regulate the activity of various transcription factors to control gene expression [64]. In addition, myostatin signaling can inhibit the IGF-1/PI3K/Akt axis and reduce p70S6K activation [65-68].

Atrogin-1 and MuRF-1 are E3 ubiquitin ligases expressed in skeletal muscle that direct the polyubiquitination of proteins to target them for proteolysis by the $26 \mathrm{~S}$ proteasome $[35,69]$. Atrogin- 1 and MuRF- 1 are induced in response to myostatin/TGF- $\beta$ signaling [66, 70-72], increase following immobilization or denervation, and mice that are deficient in atrogin-1 are resistant to denervation-induced skeletal muscle atrophy [35]. While there are clear correlations between the onset of muscle atrophy and the increase in atrogin-1 and MuRF-1, their expression can be transient $[35,73]$ making it difficult to precisely measure changes in atrogin-1 and MuRF-1 expression over time. Various transcription factors can regulate atrogin-1 and MuRF-1 mRNA expression. Smad3 appears to be important in inducing the expression of atrogin-1 in skeletal muscle, but does not appear to be important in the 
regulation of MuRF-1 expression [57, 70]. Activation of p38 MAPK induces activation of atrogin-1 [74] and MuRF-1 [75] expression, although the specific transcription factors downstream of p38 MAPK that regulate these E3 ubiquitin ligases are not known. The FoxO family of transcription factors are also important regulators of atrogin-1 and MuRF-1 gene expression, as loss of FoxO signaling inhibits the ability of muscle fibers to express atrogin-1 or MuRF-1 [76, 77]. FoxO has three isoforms in muscle, FoxO1, FoxO3, and FoxO4. When phosphorylated, all three isoforms reside in the cytosol and require dephosphorylation to enter the nucleus [37]. Akt can phosphorylate FoxO proteins, rendering them incapable of entering the nucleus to promote transcription [78]. Akt can also inhibit the ability of Smad3 to enter into the nucleus and regulate gene expression [79]. These interactions between protein synthesis and degradation pathways provide a mechanism for IGF-1 signaling to inhibit ubiquitin-mediated proteolysis.

\section{Aging-related changes in signaling pathways that regulate skeletal muscle growth and atrophy}

While skeletal muscle is known to atrophy in middle and old age, the precise mechanisms of this aging-related loss in muscle mass are not precisely understood. Several animal model studies have evaluated levels of various growth factors and cytokines that regulate muscle growth. Total IGF-1 receptor protein levels are increased in old rats but no differences in baseline IGF-1 receptor activation was observed [80]. Although IGF-1 receptor levels were elevated in response to an exercise protocol, old rats generally had reduced activation of Akt/mTOR pathways [80]. In other studies Akt phosphorylation has been reported to either be decreased $[80,81]$ or not different $[82,83]$ in old rats, and increased in old mice [84]. p70S6K activation, which is critical for protein synthesis, has been reported to the same [83] or increased [85] in old rats compared to adults. Using a synergist ablation model of muscle growth whereby the gastrocnemius muscle is partially ablated to cause growth in the synergist plantaris muscle, old rats had similar patterns of activation of the Akt/mTOR pathway as young rats, although the magnitude of increase in plantaris muscle mass was less for old rats than for young rats [86]. While there are conflicting results regarding changes in the Akt/mTOR pathway in studies using animal models of aging, most animal models of sarcopenia report an aging-related decline in muscle mass [80, 82, 84-86], suggesting that even if there is an increase in protein synthesis that occurs with aging it is not enough to keep up with other changes in the muscle that contribute to sarcopenia.

Although fewer studies evaluating aging-related changes of protein synthesis pathways in humans have been conducted, there is generally more agreement in the overall conclusions of these studies. Circulating levels of IGF-1 steadily declined from early adulthood into advanced old age [87], but local levels of IGF-1Ea and IGF-1Ec gene expression were not different between young and old subjects [88]. However, while no aging-related differences in baseline IGF-1Ea and IGF-1Ec expression were observed, in response to resistance exercise most young subjects demonstrated an increase in IGF-1Ea and IGF-1Ec expression, while most old subjects had no change or a decrease in IGF-1Ea and IGF-1Ec [88].

Compared to adults, a decrease in relative Akt phosphorylation was observed in the muscles of old humans [89]. Despite this decrease in Akt activation, relative 4EBP1 phosphorylation was not different and a decrease in nuclear localization of FoxO1 and FoxO3 was observed [89]. In response to an infusion of insulin and amino acids, both young and elderly subjects displayed activation of Akt, mTOR, and 4EBP1, but p70S6K activation was not observed in old subjects [90]. Following a bout of heavy eccentric exercise and essential amino acid intake, old subjects had a generally similar ability to activate Akt/mTOR pathways as young subjects, although the timing of the activation was slower in older subjects than in young subjects [91]. Taken together, these studies support the notion that an aging-related decline 
in IGF-1/Akt/mTOR signaling and net decreases in protein synthesis contribute to sarcopenia.

Animal model studies have also been insightful in the study of protein degradation pathways in the context of aging. There was an increase in serum [92] and local intramuscular [93] levels of TGF- $\beta$ in old mice, but no differences in intramuscular myostatin levels were observed [93]. Old animals also display elevated activation of the two main pathways downstream of the TGF- $\beta$ /myostatin receptors, Smad3 [93] and p38 MAPK [83]. Despite an aging-related increase in TGF- $\beta$ signaling, there are conflicting findings regarding agingrelated changes in the ubiquitin proteasome system. In a study evaluating the ubiquitin proteasome pathways in adult and old rats, an increase in total ubiquitinated protein content and an elevation of MuRF-1 protein levels was observed in old muscles, but atrogin-1 levels were reduced in old muscles [94]. In partial support of these findings, an increase in ubiquitinated proteins and MuRF-1 was observed in old rats, but this study reported an increase in the expression of atrogin-1 [81]. When evaluating age-related differences in the response to resistance exercise, no differences between atrogin-1 mRNA levels were observed at baseline for adult and old rats [80]. However, $48 \mathrm{~h}$ following a resistance exercise bout, adult rats had significantly higher levels of atrogin-1 expression, where no changes were observed in exercised old muscles [80]. For rats fed with a standard diet ad libidum, an aging-related decrease in atrogin-1 and MuRF-1 expression was observed, but interestingly old rats fed a calorie restricted diet that was $70 \%$ of ad libidum intake had higher levels of atrogin-1 and MuRF-1 than old rats fed ad libidum [82]. Despite an elevation in atrogin-1 and MuRF-1, the muscles from the calorie restricted rats maintained much more mass than the ad libidum rats [82]. Another study identified no aging-related differences in atrogin-1 and MuRF-1 expression in adult and old muscles of mice [84]. While there is a tremendous amount of disagreement between studies, the animal literature as a whole supports the notion that TGF- $\beta$ signaling, along with atrogin- 1 and MuRF-1, likely play some role in contributing to the aging-related decreases in muscle mass.

In humans, the ubiquitin proteasome system appears to function as efficiently in old muscle as it does in adult muscle [95], and aging-related increases in total intramuscular ubiquitin content have been reported [96], but there is conflicting data regarding the molecular mechanisms that regulate ubiquitin-mediated proteolysis in human muscle. There was an increase in serum levels of TGF- $\beta$ in old humans [92], but circulating levels of myostatin were not different between young and older subjects [97]. Despite no detectable increase in circulating myostatin levels, local intramuscular levels of myostatin are elevated with aging in humans [89]. For the E3 ubiquitin ligases, atrogin-1 expression was not different for adult and old subjects $[89,98,99]$, and MuRF-1 levels have been reported to either not change $[89,99]$ or increase with aging [98]. There also appears to be a differential response of atrogin-1 and MuRF-1 to training in elderly subjects. Following a single bout of resistance exercise, for both adult and old subjects there was an increase in MuRF-1, but only the old subjects had an increase in atrogin-1 [98]. It is difficult to draw definitive conclusions at this time, especially given the difficulty in tracking the expression of atrogin-1 and MuRF-1 in a longitudinal fashion, but the increased level of ubiquitin-conjugated proteins and elevated levels of intramuscular myostatin suggest that the ubiquitin proteasome system likely contributes to sarcopenia in humans.

\section{Targeting atrogin-1 and MuRF-1 to maintain strength and muscle mass in the elderly}

Developing therapies for the prevention and treatment of sarcopenia will not only help to enhance the quality of life for individual patients who suffer from this disease but also for reduction in economic and productivity burdens associated with sarcopenia would be 
beneficial to society as a whole. The current first-line therapy for preventing and treating sarcopenia is resistance exercise. Resistance exercise can directly increase skeletal muscle mass and strength, and also have positive effects on metabolic, cardiovascular, and reproductive systems [100]. While younger patients tend to have an increased magnitude of improvement in strength from resistance exercise, elderly patients can also increase strength and mobility, even into the ninth decade of life [101, 102]. Following a single bout of resistance exercise, older subjects not only have blunted responses to activation of the Akt/ mTOR pathway [103] but also have a reduced myostatin expression and enhanced expression of myogenic genes [104]. Despite small changes following an acute resistance training session, long-term ( $>3$ month) resistance training programs have been shown to increase the size and force generating capacity of muscle fibers from elderly subjects, especially type I muscle fibers $[12,105,106]$. Chronic resistance training also increases Akt phosphorylation and the nuclear accumulation of FoxO3, but no differences in MuRF-1 or atrogin-1 expression were observed [107]. Interestingly, although resistance training is typically associated with the most profound gains in strength, elderly subjects who completed a 3-month moderate intensity aerobic program also demonstrated marked increases in whole muscle size and strength [108]. Subjects also experienced an increase in type I muscle fibers, and a reduction in myostatin and FoxO3 expression, although atrogin-1 and MuRF-1 expression were not different $[108,109]$. While the molecular mechanisms are still not fully understood, the results from resistance training and aerobic training studies suggest that exercise can be a highly effective tool to combat the aging-related loss in muscle mass.

For patients who are non-ambulatory or have co-morbidities that would preclude participation in resistance training exercises, such as moderate to severe osteoarthritis [110] or certain forms of unstable cardiovascular disease [111], developing pharmacological therapies for the prevention and treatment of sarcopenia is important. A 4-week long course of IGF-1 administration resulted in increased skeletal muscle protein synthesis rates, although measurements of muscle size and strength were not performed [112]. Given the aging-related increases in myostatin that has been observed in humans [89] and its profound effects on muscle mass, myostatin inhibition is also a potential therapeutic target for the prevention and treatment of sarcopenia. Using a bioneutralizing antibody against myostatin, there was increased ambulatory activity and metabolic rates of aged mice [113], and also increased muscle force production and reduced atrogin-1 expression [114]. Losartan is an angiotensin II receptor antagonist commonly used not only to treat high blood pressure but also can antagonize TGF- $\beta$ signaling in skeletal muscle [115]. In a mouse model of aging disuse atrophy, losartan decreased the activation of p38 MAPK, increased Akt and mTOR activation, prevented muscle fiber atrophy, and reduced muscle fibrosis [116]. The IGF-1, myostatin, and TGF- $\beta$ signaling pathways appear to be attractive drug targets for the prevention and treatment of sarcopenia, although we are currently at a very early stage in developing and validating potential pharmacological therapies.

\section{Conclusions}

Sarcopenia is a major public health problem that is anticipated to grow as our population ages, but we are still at an early stage of understanding the molecular mechanisms that lead to sarcopenia. In vitro and in vivo studies in animal models and humans are somewhat contradictory, but the ubiquitin proteasome system appears to play a role in sarcopenia. Atrogin-1 and MuRF-1 have been identified as important enzymes in ubiquitin-mediated proteolysis and muscle atrophy, and modulating their expression via physical activity or targeting the upstream cytokines and growth factors that regulate their expression has the potential to prevent or reverse muscle atrophy in patients with sarcopenia. Now that widely accepted standards for the screening and diagnosis of sarcopenia are in place, further large- 
scale longitudinal studies are necessary to fully evaluate the role of the ubiquitin proteasome system in aging-related muscle wasting and for the potential of modulating this system to restore muscle mass and strength in patients suffering from sarcopenia.

\section{Acknowledgments}

This work was supported by grant AG024824 from the National Institute on Aging.

\section{References}

1. Rosenberg IH. Summary comments. Am. J. Clin. Nutr. 1989; 50(5):1231-1233.

2. Fielding RA, Vellas B, Evans WJ, Bhasin S, Morley JE, Newman AB, Abellan van Kan G, Andrieu S, Bauer J, Breuille D, Cederholm T, Chandler J, De Meynard C, Donini L, Harris T, Kannt A, Keime Guibert F, Onder G, Papanicolaou D, Rolland Y, Rooks D, Sieber C, Souhami E, Verlaan S, Zamboni M. Sarcopenia: an undiagnosed condition in older adults. Current consensus definition: prevalence, etiology, and consequences. International working group on sarcopenia. J. Am. Med. Dir. Assoc. 2011; 12(4):249-256. doi:10.1016/j.jamda.2011.01.003. [PubMed: 21527165]

3. Janssen I. The epidemiology of sarcopenia. Clin. Geriatr. Med. 2011; 27(3):355-363. doi:10.1016/ j.cger.2011.03.004. [PubMed: 21824552]

4. Evans CJ, Chiou C-F, Fitzgerald KA, Evans WJ, Ferrell BR, Dale W, Fried LP, Gandra SR, Dennee-Sommers B, Patrick DL. Development of a new patient-reported outcome measure in sarcopenia. J. Am. Med. Dir. Assoc. 2011; 12(3):226-233. doi:10.1016/j.jamda.2010.09.010. [PubMed: 21333926]

5. Janssen I, Shepard DS, Katzmarzyk PT, Roubenoff R. The healthcare costs of sarcopenia in the United States. J. Am. Geriatr. Soc. 2004; 52(1):80-85. [PubMed: 14687319]

6. Morley JE. Sarcopenia: diagnosis and treatment. J. Nutr. Health Aging. 2008; 12(7):452-456. [PubMed: 18615226]

7. Faulkner JA, Davis CS, Mendias CL, Brooks SV. The aging of elite male athletes: age-related changes in performance and skeletal muscle structure and function. Clin. J. Sport Med. 2008; 18(6): 501-507. doi:10.1097/JSM.0b013e3181845f1c. [PubMed: 19001883]

8. Janssen I, Heymsfield SB, Wang ZM, Ross R. Skeletal muscle mass and distribution in 468 men and women aged 18-88 yr. J. Appl. Physiol. 2000; 89(1):81-88. [PubMed: 10904038]

9. Lexell J. Human aging, muscle mass, and fiber type composition. J. Gerontol. Ser. A Biol. Sci. Med. Sci. 1995; 50:11-16. [PubMed: 7493202]

10. Power GA, Dalton BH, Behm DG, Vandervoort AA, Doherty TJ, Rice CL. Motor unit number estimates in masters runners: use it or lose it? Med. Sci. Sports Exerc. 2010; 42(9):1644-1650. doi:10.1249/MSS.0b013e3181d6f9e9. [PubMed: 20142771]

11. Trappe S, Gallagher P, Harber M, Carrithers J, Fluckey J, Trappe T. Single muscle fibre contractile properties in young and old men and women. J. Physiol. 2003; 552(Pt 1):47-58. doi:10.1113/ jphysiol.2003.044966. [PubMed: 12837929]

12. Claflin DR, Larkin LM, Cederna PS, Horowitz JF, Alexander NB, Cole NM, Galecki AT, Chen S, Nyquist LV, Carlson BM, Faulkner JA, Ashton-Miller JA. Effects of high- and low-velocity resistance training on the contractile properties of skeletal muscle fibers from young and older humans. J. Appl. Physiol. 2011; 111(4):1021-1030. doi:10.1152/japplphysiol.01119.2010.

[PubMed: 21799130]

13. Lexell J, Taylor CC, Sjostrom M. What is the cause of the ageing atrophy? Total number, size and proportion of different fiber types studied in whole vastus lateralis muscle from 15- to 83-year-old men. J. Neurol. Sci. 1988; 84(2-3):275-294. [PubMed: 3379447]

14. Favier F, Benoit H, Freyssenet D. Cellular and molecular events controlling skeletal muscle mass in response to altered use. Pflügers Archiv. 2008; 456(3):587-600. doi:10.1007/s00424-007-0423z. [PubMed: 18193272]

15. Hawke TJ, Garry DJ. Myogenic satellite cells: physiology to molecular biology. J. Appl. Physiol. 2001; 91(2):534-551. [PubMed: 11457764] 
16. Conboy IM, Rando TA. Aging, stem cells and tissue regeneration: lessons from muscle. Cell Cycle. 2005; 4(3):407-410. [PubMed: 15725724]

17. Kadi F, Charifi N, Denis C, Lexell J. Satellite cells and myonuclei in young and elderly women and men. Muscle Nerve. 2004; 29(1):120-127. doi:10.1002/mus.10510. [PubMed: 14694507]

18. Carlson BM, Faulkner JA. Muscle transplantation between young and old rats: age of host determines recovery. Am. J. Physiol. 1989; 256(6 Pt 1):C1262-C1266. [PubMed: 2735398]

19. Conboy IM, Conboy MJ, Wagers AJ, Girma ER, Weissman IL, Rando TA. Rejuvenation of aged progenitor cells by exposure to a young systemic environment. Nature. 2005; 433(7027):760-764. doi:10.1038/nature03260. [PubMed: 15716955]

20. Mouly V, Aamiri A, Bigot A, Cooper RN, Di Donna S, Furling D, Gidaro T, Jacquemin V, Mamchaoui K, Negroni E, Périé S, Renault V, Silva-Barbosa SD, Butler-Browne GS. The mitotic clock in skeletal muscle regeneration, disease and cell mediated gene therapy. Acta Physiol. Scand. 2005; 184(1):3-15. doi:10.1111/j.1365-201X.2005.01417.x. [PubMed: 15847639]

21. Reznick RM, Zong H, Li J, Morino K, Moore IK, Yu HJ, Liu ZX, Dong J, Mustard KJ, Hawley SA, Befroy D, Pypaert M, Hardie DG, Young LH, Shulman GI. Aging-associated reductions in AMP-activated protein kinase activity and mitochondrial biogenesis. Cell Metab. 2007; 5(2):151156. doi:10.1016/j.cmet.2007.01.008. [PubMed: 17276357]

22. Brunk UT, Terman A. The mitochondrial-lysosomal axis theory of aging: accumulation of damaged mitochondria as a result of imperfect autophagocytosis. Eur. J. Biochem. 2002; 269(8): 1996-2002. [PubMed: 11985575]

23. Marzetti E, Lawler JM, Hiona A, Manini T, Seo AY, Leeuwenburgh C. Modulation of age-induced apoptotic signaling and cellular remodeling by exercise and calorie restriction in skeletal muscle. Free Radic. Biol. Med. 2008; 44(2):160-168. doi:10.1016/j.freeradbiomed.2007.05.028. [PubMed: 18191752]

24. Marzetti E, Hwang JCY, Lees HA, Wohlgemuth SE, Dupont-Versteegden EE, Carter CS, Bernabei R, Leeuwenburgh C. Mitochondrial death effectors: relevance to sarcopenia and disuse muscle atrophy. Biochim. Biophys. Acta. 2010; 1800(3):235-244. doi:10.1016/j.bbagen.2009.05.007. [PubMed: 19450666]

25. Musaro A, McCullagh K, Paul A, Houghton L, Dobrowolny G, Molinaro M, Barton ER, Sweeney HL, Rosenthal N. Localized Igf-1 transgene expression sustains hypertrophy and regeneration in senescent skeletal muscle. Nat. Genet. 2001; 27(2):195-200. doi:10.1038/84839. [PubMed: 11175789]

26. Mavalli MD, DiGirolamo DJ, Fan Y, Riddle RC, Campbell KS, van Groen T, Frank SJ, Sperling MA, Esser KA, Bamman MM, Clemens TL. Distinct growth hormone receptor signaling modes regulate skeletal muscle development and insulin sensitivity in mice. J. Clin. Investig. 2010; 120(11):4007-4020. doi:10.1172/JCI42447. [PubMed: 20921627]

27. Marone, Mozzetti; Ritis, D.; Pierelli, Scambia. Semiquantitative RT-PCR analysis to assess the expression levels of multiple transcripts from the same sample. Biol Proced Online. 2001; 3:1925. doi:10.1251/bpo20. [PubMed: 12734582]

28. Schiaffino S, Mammucari C. Regulation of skeletal muscle growth by the IGF1-Akt/PKB pathway: insights from genetic models. Skelet. Muscle. 2011; 1(1):4. doi:10.1186/2044-5040-1-4. [PubMed: 21798082]

29. Miyazaki M, McCarthy JJ, Esser KA. Insulin like growth factor-1-induced phosphorylation and altered distribution of tuberous sclerosis complex (TSC)1/TSC2 in C2C12 myotubes. FEBS J. 2010; 277(9):2180-2191. doi:10.1111/j.1742-4658.2010.07635.x. [PubMed: 20412061]

30. Andjelkovic M, Alessi DR, Meier R, Fernandez A, Lamb NJ, Frech M, Cron P, Cohen P, Lucocq JM, Hemmings BA. Role of translocation in the activation and function of protein kinase B. J. Biol. Chem. 1997; 272(50):31515-31524. [PubMed: 9395488]

31. Vivanco I, Sawyers CL. The phosphatidylinositol 3-kinase AKT pathway in human cancer. Nat. Rev. Cancer. 2002; 2(7):489-501. doi:10.1038/nrc839. [PubMed: 12094235]

32. Goldspink G. Mechanical signals, IGF-I gene splicing, and muscle adaptation. Physiology. 2005; 20:232-238. doi:10.1152/physiol.00004.2005. [PubMed: 16024511] 
33. Matheny RW, Nindl BC, Adamo ML. Minireview: mechano-growth factor: a putative product of IGF-I gene expression involved in tissue repair and regeneration. Endocrinology. 2010; 151(3): 865-875. doi:10.1210/en.2009-1217. [PubMed: 20130113]

34. Vinciguerra M, Musarò A, Rosenthal N. Regulation of muscle atrophy in aging and disease. Adv. Exp. Med. Biol. 2010; 694:211-233. [PubMed: 20886766]

35. Bodine SC, Latres E, Baumhueter S, Lai VK, Nunez L, Clarke BA, Poueymirou WT, Panaro FJ, Na E, Dharmarajan K, Pan ZQ, Valenzuela DM, DeChiara TM, Stitt TN, Yancopoulos GD, Glass DJ. Identification of ubiquitin ligases required for skeletal muscle atrophy. Science. 2001; 294(5547):1704-1708. doi:10.1126/science.1065874. [PubMed: 11679633]

36. Rommel C, Bodine SC, Clarke BA, Rossman R, Nunez L, Stitt TN, Yancopoulos GD, Glass DJ. Mediation of IGF-1-induced skeletal myotube hypertrophy by PI(3)K/Akt/mTOR and PI(3)K/Akt/ GSK3 pathways. Nat. Cell Biol. 2001; 3(11):1009-1013. doi:10.1038/ncb1101-1009. [PubMed: 11715022]

37. Sandri M. Signaling in muscle atrophy and hypertrophy. Physiology. 2008; 23:160-170. doi: 10.1152/physiol.00041.2007. [PubMed: 18556469]

38. Song Y-H, Godard M, Li Y, Richmond SR, Rosenthal N, Delafontaine P. Insulin-like growth factor I-mediated skeletal muscle hypertrophy is characterized by increased mTOR-p70S6K signaling without increased Akt phosphorylation. J. Investig. Med. 2005; 53(3):135-142.

39. Frost RA, Lang CH. mTor signaling in skeletal muscle during sepsis and inflammation: where does it all go wrong? Physiology. 2011; 26(2):83-96. doi:10.1152/physiol.00044.2010. [PubMed: 21487027]

40. Inoki K, Li Y, Zhu T, Wu J, Guan KL. TSC2 is phosphorylated and inhibited by Akt and suppresses mTOR signalling. Nat. Cell Biol. 2002; 4(9):648-657. doi:10.1038/ncb839. [PubMed: 12172553]

41. Raught B, Peiretti F, Gingras AC, Livingstone M, Shahbazian D, Mayeur GL, Polakiewicz RD, Sonenberg N, Hershey JW. Phosphorylation of eucaryotic translation initiation factor 4B Ser422 is modulated by S6 kinases. EMBO J. 2004; 23(8):1761-1769. doi:10.1038/sj.emboj.7600193. [PubMed: 15071500]

42. Zoncu R, Efeyan A, Sabatini DM. mTOR: from growth signal integration to cancer, diabetes and ageing. Nat. Rev. Mol. Cell Biol. 2011; 12(1):21-35. doi:10.1038/nrm3025. [PubMed: 21157483]

43. Hara K, Yonezawa K, Kozlowski MT, Sugimoto T, Andrabi K, Weng QP, Kasuga M, Nishimoto I, Avruch J. Regulation of eIF-4E BP1 phosphorylation by mTOR. J. Biol. Chem. 1997; 272(42): 26457-26463. [PubMed: 9334222]

44. Izumiya Y, Hopkins T, Morris C, Sato K, Zeng L, Viereck J, Hamilton JA, Ouchi N, LeBrasseur NK, Walsh K. Fast/Glycolytic muscle fiber growth reduces fat mass and improves metabolic parameters in obese mice. Cell Metab. 2008; 7(2):159-172. doi:10.1016/j.cmet.2007.11.003. [PubMed: 18249175]

45. Pallafacchina G, Calabria E, Serrano AL, Kalhovde JM, Schiaffino S. A protein kinase Bdependent and rapamycin-sensitive pathway controls skeletal muscle growth but not fiber type specification. Proc. Natl. Acad. Sci. USA. 2002; 99(14):9213-9218. doi:10.1073/pnas.142166599. [PubMed: 12084817]

46. Miyazaki M, Esser KA. Cellular mechanisms regulating protein synthesis and skeletal muscle hypertrophy in animals. J. Appl. Physiol. 2009; 106(4):1367-1373. doi:10.1152/japplphysiol. 91355.2008. [PubMed: 19036895]

47. Marzetti E, Privitera G, Simili V, Wohlgemuth SE, Aulisa L, Pahor M, Leeuwenburgh C. Multiple pathways to the same end: mechanisms of myonuclear apoptosis in sarcopenia of aging. Scientific World J. 2010; 10:340-349. doi:10.1100/tsw.2010.27.

48. Buford TW, Anton SD, Judge AR, Marzetti E, Wohlgemuth SE, Carter CS, Leeuwenburgh C, Pahor M, Manini TM. Models of accelerated sarcopenia: critical pieces for solving the puzzle of age-related muscle atrophy. Ageing Res. Rev. 2010; 9(4):369-383. doi:10.1016/j.arr.2010.04.004. [PubMed: 20438881]

49. McPherron AC, Lawler AM, Lee SJ. Regulation of skeletal muscle mass in mice by a new TGFbeta superfamily member. Nature. 1997; 387(6628):83-90. doi:10.1038/387083a0. [PubMed: 9139826] 
50. Mendias CL, Marcin JE, Calerdon DR, Faulkner JA. Contractile properties of EDL and soleus muscles of myostatin-deficient mice. J. Appl. Physiol. 2006; 101(3):898-905. doi:10.1152/ japplphysiol.00126.2006. [PubMed: 16709649]

51. Gentry BA, Ferreira JA, Phillips CL, Brown M. Hindlimb skeletal muscle function in myostatindeficient mice. Muscle Nerve. 2011; 43(1):49-57. doi:10.1002/mus.21796. [PubMed: 21082689]

52. Zimmers TA, Davies MV, Koniaris LG, Haynes P, Esquela AF, Tomkinson KN, McPherron AC, Wolfman NM, Lee S-J. Induction of cachexia in mice by systemically administered myostatin. Science. 2002; 296(5572):1486-1488. doi:10.1126/science.1069525. [PubMed: 12029139]

53. Mendias CL, Gumucio JP, Davis ME, Bromley CW, Davis CS, Brooks SV. Transforming growth factor-beta induces skeletal muscle atrophy and fibrosis through the induction of atrogin-1 and scleraxis. Muscle Nerve. 2012; 45(1):55-59. doi:10.1002/mus.22232. [PubMed: 22190307]

54. Lee SJ, Lee YS, Zimmers TA, Soleimani A, Matzuk MM, Tsuchida K, Cohn RD, Barton ER. Regulation of muscle mass by follistatin and activins. Mol. Endocrinol. 2010; 24(10):1998-2008. doi:10.1210/me.2010-0127. [PubMed: 20810712]

55. Lee SJ, McPherron AC. Regulation of myostatin activity and muscle growth. Proc. Natl. Acad. Sci. USA. 2001; 98(16):9306-9311. doi:10.1073/pnas.151270098. [PubMed: 11459935]

56. Philip B, Lu Z, Gao Y. Regulation of GDF-8 signaling by the p38 MAPK. Cell. Signal. 2005; 17(3):365-375. doi:10.1016/j.cellsig.2004.08.003. [PubMed: 15567067]

57. Sartori R, Milan G, Patron M, Mammucari C, Blaauw B, Abraham R, Sandri M. Smad 2 and 3 transcription factors control muscle mass in adulthood. Am. J. Physiol. Cell Physiol. 2009; 296(6):C1248-C1257. doi:10.1152/ajpcell.00104.2009. [PubMed: 19357234]

58. Shi Y, Massagué J. Mechanisms of TGF-beta signaling from cell membrane to the nucleus. Cell. 2003; 113(6):685-700. [PubMed: 12809600]

59. Yu L, Hébert MC, Zhang YE. TGF-beta receptor-activated p38 MAP kinase mediates Smadindependent TGF-beta responses. EMBO J. 2002; 21(14):3749-3759. doi:10.1093/emboj/cdf366. [PubMed: 12110587]

60. Zhu X, Topouzis S, Liang L-F, Stotish RL. Myostatin signaling through Smad2, Smad3 and Smad4 is regulated by the inhibitory Smad7 by a negative feedback mechanism. Cytokine. 2004; 26(6):262-272. doi:10.1016/j.cyto.2004.03.007. [PubMed: 15183844]

61. Kollias HD, McDermott JC. Transforming growth factor-beta and myostatin signaling in skeletal muscle. J. Appl. Physiol. 2008; 104(3):579-587. doi:10.1152/japplphysiol.01091.2007. [PubMed: 18032576]

62. Gomis RR, Alarcón C, He W, Wang Q, Seoane J, Lash A, Massagué J. A FoxO-Smad synexpression group in human keratinocytes. Proc. Natl. Acad. Sci. USA. 2006; 103(34):1274712752. doi:10.1073/pnas.0605333103. [PubMed: 16908841]

63. Seoane J, Le H-V, Shen L, Anderson SA, Massagué J. Integration of Smad and forkhead pathways in the control of neuroepithelial and glioblastoma cell proliferation. Cell. 2004; 117(2):211-223. [PubMed: 15084259]

64. Zarubin T, Han J. Activation and signaling of the p38 MAP kinase pathway. Cell Res. 2005; 15(1): 11-18. doi:10.1038/sj.cr.7290257. [PubMed: 15686620]

65. Amirouche A, Durieux A-C, Banzet S, Koulmann N, Bonnefoy R, Mouret C, Bigard X, Peinnequin A, Freyssenet D. Down-regulation of Akt/mammalian target of rapamycin signaling pathway in response to myostatin overexpression in skeletal muscle. Endocrinology. 2009; 150(1): 286-294. doi:10.1210/en.2008-0959. [PubMed: 18801898]

66. McFarlane C, Plummer E, Thomas M, Hennebry A, Ashby M, Ling N, Smith H, Sharma M, Kambadur R. Myostatin induces cachexia by activating the ubiquitin proteolytic system through an NF-kappaB-independent, FoxO1-dependent mechanism. J. Cell. Physiol. 2006; 209(2):501514. doi:10.1002/jcp.20757. [PubMed: 16883577]

67. Trendelenburg AU, Meyer A, Rohner D, Boyle J, Hatakeyama S, Glass DJ. Myostatin reduces Akt/TORC1/p70S6K signaling, inhibiting myoblast differentiation and myotube size. Am. J. Physiol. Cell Physiol. 2009; 296(6):C1258-C1270. doi:10.1152/ajpcell.00105.2009. [PubMed: 19357233]

68. Yang W, Zhang Y, Li Y, Wu Z, Zhu D. Myostatin induces cyclin D1 degradation to cause cell cycle arrest through a phosphatidylinositol 3-kinase/AKT/GSK-3 beta pathway and is antagonized 
by insulin-like growth factor 1. J. Biol. Chem. 2007; 282(6):3799-3808. doi:10.1074/ jbc.M610185200. [PubMed: 17130121]

69. Gomes MD, Lecker SH, Jagoe RT, Navon A, Goldberg AL. Atrogin-1, a muscle-specific F-box protein highly expressed during muscle atrophy. Proc. Natl. Acad. Sci. USA. 2001; 98(25):1444014445. doi:10.1073/pnas.251541198. [PubMed: 11717410]

70. Lokireddy S, McFarlane C, Ge X, Zhang H, Sze SK, Sharma M, Kambadur R. Myostatin induces degradation of sarcomeric proteins through a Smad3 signaling mechanism during skeletal muscle wasting. Mol. Endocrinol. 2011; 25(11):1936-1949. doi:10.1210/me.2011-1124. [PubMed: 21964591]

71. Mendias CL, Gumucio JP, Lynch EB. Mechanical loading and TGF-beta change the expression of multiple miRNAs in tendon fibroblasts. J. Appl. Physiol. 2012 doi:10.1152/japplphysiol. 00301.2012.

72. Mendias CL, Kayupov E, Bradley JR, Brooks SV, Claflin DR. Decreased specific force and power production of muscle fibers from myostatin-deficient mice are associated with a suppression of protein degradation. J. Appl. Physiol. 2011; 111(1):185-191. doi:10.1152/japplphysiol. 00126.2011. [PubMed: 21565991]

73. Sacheck JM, Hyatt J-PK, Raffaello A, Jagoe RT, Roy RR, Edgerton VR, Lecker SH, Goldberg AL. Rapid disuse and denervation atrophy involve transcriptional changes similar to those of muscle wasting during systemic diseases. FASEB J. 2007; 21(1):140-155. doi:10.1096/fj.06-6604com. [PubMed: 17116744]

74. Li Y-P, Chen Y, John J, Moylan J, Jin B, Mann DL, Reid MB. TNF-alpha acts via p38 MAPK to stimulate expression of the ubiquitin ligase atrogin1/MAFbx in skeletal muscle. FASEB J. 2005; 19(3):362-370. doi:10.1096/fj.04-2364com. [PubMed: 15746179]

75. McClung JM, Judge AR, Powers SK, Yan Z. p38 MAPK links oxidative stress to autophagyrelated gene expression in cachectic muscle wasting. Am. J. Physiol. Cell Physiol. 2010; 298(3):C542-C549. doi:10.1152/ajpcell.00192.2009. [PubMed: 19955483]

76. McLoughlin TJ, Smith SM, DeLong AD, Wang H, Unterman TG, Esser KA. FoxO1 induces apoptosis in skeletal myotubes in a DNA-binding-dependent manner. Am. J. Physiol. Cell Physiol. 2009; 297(3):C548-C555. doi:10.1152/ajpcell.00502.2008. [PubMed: 19553561]

77. Senf SM, Dodd SL, Judge AR. FOXO signaling is required for disuse muscle atrophy and is directly regulated by Hsp70. Am. J. Physiol. Cell Physiol. 2010; 298(1):C38-C45. doi:10.1152/ ajpcell.00315.2009. [PubMed: 19864323]

78. Stitt TN, Drujan D, Clarke BA, Panaro F, Timofeyva Y, Kline WO, Gonzalez M, Yancopoulos GD, Glass DJ. The IGF-1/PI3K/Akt pathway prevents expression of muscle atrophy-induced ubiquitin ligases by inhibiting FOXO transcription factors. Mol. Cell. 2004; 14(3):395-403. [PubMed: 15125842]

79. Conery AR, Cao Y, Thompson EA, Townsend CM, Ko TC, Luo K. Akt interacts directly with Smad3 to regulate the sensitivity to TGF-beta induced apoptosis. Nat. Cell Biol. 2004; 6(4):366372. [PubMed: 15104092]

80. Haddad F, Adams GR. Aging-sensitive cellular and molecular mechanisms associated with skeletal muscle hypertrophy. J. Appl. Physiol. 2006; 100(4):1188-1203. doi:10.1152/japplphysiol. 01227.2005. [PubMed: 16373446]

81. Clavel S, Coldefy A-S, Kurkdjian E, Salles J, Margaritis I, Derijard B. Atrophy-related ubiquitin ligases, atrogin-1 and MuRF1 are up-regulated in aged rat Tibialis Anterior muscle. Mech. Ageing Dev. 2006; 127(10):794-801. doi:10.1016/j.mad.2006.07.005. [PubMed: 16949134]

82. Edström E, Altun M, Hägglund M, Ulfhake B. Atrogin-1/MAFbx and MuRF1 are downregulated in aging-related loss of skeletal muscle. J. Gerontol. Ser. A Biol. Sci. Med. Sci. 2006; 61(7):663674. [PubMed: 16870627]

83. Rahnert JA, Luo Q, Balog EM, Sokoloff AJ, Burkholder TJ. Changes in growth-related kinases in head, neck and limb muscles with age. Exp. Gerontol. 2011; 46(4):282-291. doi:10.1016/j.exger. 2010.11.004. [PubMed: 21095226]

84. Gaugler M, Brown A, Merrell E, DiSanto-Rose M, Rathmacher JA, Reynolds TH. PKB signaling and atrogene expression in skeletal muscle of aged mice. J. Appl. Physiol. 2011; 111(1):192-199. doi:10.1152/japplphysiol.00175.2011. [PubMed: 21551011] 
85. Kimball SR, O’Malley JP, Anthony JC, Crozier SJ, Jefferson LS. Assessment of biomarkers of protein anabolism in skeletal muscle during the life span of the rat: sarcopenia despite elevated protein synthesis. Am. J. Physiol. Endocrinol. Metab. 2004; 287(4):E772-E780. doi:10.1152/ ajpendo.00535.2003. [PubMed: 15187001]

86. Chalé-Rush A, Morris EP, Kendall TL, Brooks NE, Fielding RA. Effects of chronic overload on muscle hypertrophy and mTOR signaling in young adult and aged rats. J. Gerontol. Ser. A Biol. Sci. Med. Sci. 2009; 64(12):1232-1239. doi:10.1093/gerona/glp146. [PubMed: 19808838]

87. O'Connor KG, Tobin JD, Harman SM, Plato CC, Roy TA, Sherman SS, Blackman MR. Serum levels of insulin-like growth factor-I are related to age and not to body composition in healthy women and men. J. Gerontol. Ser. A Biol. Sci. Med. Sci. 1998; 53(3):M176-M182. [PubMed: 9597048]

88. Hameed M, Orrell RW, Cobbold M, Goldspink G, Harridge SDR. Expression of IGF-I splice variants in young and old human skeletal muscle after high resistance exercise. J. Physiol. 2003; 547(Pt 1):247-254. doi:10.1113/jphysiol.2002.032136. [PubMed: 12562960]

89. Léger B, Derave W, De Bock K, Hespel P, Russell AP. Human sarcopenia reveals an increase in SOCS-3 and myostatin and a reduced efficiency of Akt phosphorylation. Rejuvenation Res. 2008; 11(1):163B-175B. doi:10.1089/rej.2007.0588. [PubMed: 18240972]

90. Guillet C, Prod'homme M, Balage M, Gachon P, Giraudet C, Morin L, Grizard J, Boirie Y. Impaired anabolic response of muscle protein synthesis is associated with S6K1 dysregulation in elderly humans. FASEB J. 2004; 18(13):1586-1587. doi:10.1096/fj.03-1341fje. [PubMed: 15319361]

91. Drummond MJ, Dreyer HC, Pennings B, Fry CS, Dhanani S, Dillon EL, Sheffield-Moore M, Volpi E, Rasmussen BB. Skeletal muscle protein anabolic response to resistance exercise and essential amino acids is delayed with aging. J. Appl. Physiol. 2008; 104(5):1452-1461. doi:10.1152/ japplphysiol.00021.2008. [PubMed: 18323467]

92. Carlson ME, Conboy MJ, Hsu M, Barchas L, Jeong J, Agrawal A, Mikels AJ, Agrawal S, Schaffer DV, Conboy IM. Relative roles of TGF-beta1 and Wnt in the systemic regulation and aging of satellite cell responses. Aging Cell. 2009; 8(6):676-689. doi:10.1111/j.1474-9726.2009.00517.x. [PubMed: 19732043]

93. Carlson ME, Hsu M, Conboy IM. Imbalance between pSmad3 and Notch induces CDK inhibitors in old muscle stem cells. Nature. 2008; 454(7203):528-532. doi:10.1038/nature07034. [PubMed: 18552838]

94. Altun M, Besche HC, Overkleeft HS, Piccirillo R, Edelmann MJ, Kessler BM, Goldberg AL, Ulfhake B. Muscle wasting in aged, sarcopenic rats is associated with enhanced activity of the ubiquitin proteasome pathway. J. Biol. Chem. 2010; 285(51):39597-39608. doi:10.1074/ jbc.M110.129718. [PubMed: 20940294]

95. Bossola M, Pacelli F, Costelli P, Tortorelli A, Rosa F, Doglietto GB. Proteasome activities in the rectus abdominis muscle of young and older individuals. Biogerontology. 2008; 9(4):261-268. doi:10.1007/s10522-008-9135-9. [PubMed: 18330717]

96. Cai D, Lee KKH, Li M, Tang MK, Chan KM. Ubiquitin expression is up-regulated in human and rat skeletal muscles during aging. Arch. Biochem. Biophys. 2004; 425(1):42-50. doi:10.1016/ j.abb.2004.02.027. [PubMed: 15081892]

97. Ratkevicius A, Joyson A, Selmer I, Dhanani T, Grierson C, Tommasi AM, Devries A, Rauchhaus P, Crowther D, Alesci S, Yaworsky P, Gilbert F, Redpath TW, Brady J, Fearon KCH, Reid DM, Greig CA, Wackerhage H. Serum concentrations of myostatin and myostatin-interacting proteins do not differ between young and sarcopenic elderly men. J. Gerontol. Ser. A Biol. Sci. Med. Sci. 2011 doi:10.1093/gerona/glr025.

98. Raue U, Slivka D, Jemiolo B, Hollon C, Trappe S. Proteolytic gene expression differs at rest and after resistance exercise between young and old women. J. Gerontol. Ser. A Biol. Sci. Med. Sci. 2007; 62(12):1407-1412. [PubMed: 18166693]

99. Whitman SA, Wacker MJ, Richmond SR, Godard MP. Contributions of the ubiquitin-proteasome pathway and apoptosis to human skeletal muscle wasting with age. Pflügers Archiv. 2005; 450(6): 437-446. doi:10.1007/s00424-005-1473-8. [PubMed: 15952031]

100. Di Luigi L, Romanelli F, Sgrò P, Lenzi A. Andrological aspects of physical exercise and sport medicine. Endocrine. 2012 doi:10.1007/s12020-012-9655-6. 
101. Forbes SC, Little JP, Candow DG. Exercise and nutritional interventions for improving aging muscle health. Endocrine. 2012 doi:10.1007/s12020-012-9676-1.

102. Liu CK, Fielding RA. Exercise as an intervention for frailty. Clin. Geriatr. Med. 2011; 27(1):101110. doi:10.1016/j.cger.2010.08.001. [PubMed: 21093726]

103. Fry CS, Drummond MJ, Glynn EL, Dickinson JM, Gundermann DM, Timmerman KL, Walker DK, Dhanani S, Volpi E, Rasmussen BB. Aging impairs contraction-induced human skeletal muscle mTORC1 signaling and protein synthesis. Skelet. Muscle. 2011; 1(1):11. doi: 10.1186/2044-5040-1-11. [PubMed: 21798089]

104. Raue U, Slivka D, Jemiolo B, Hollon C, Trappe S. Myogenic gene expression at rest and after a bout of resistance exercise in young (18-30 yr) and old (80-89 yr) women. J. Appl. Physiol. 2006; 101(1):53-59. doi:10.1152/japplphysiol.01616.2005. [PubMed: 16601301]

105. Trappe S, Godard M, Gallagher P, Carroll C, Rowden G, Porter D. Resistance training improves single muscle fiber contractile function in older women. Am. J. Physiol. Cell Physiol. 2001; 281(2):C398-C406. [PubMed: 11443039]

106. Trappe S, Williamson D, Godard M, Porter D, Rowden G, Costill D. Effect of resistance training on single muscle fiber contractile function in older men. J. Appl. Physiol. 2000; 89(1):143-152. [PubMed: 10904046]

107. Williamson DL, Raue U, Slivka DR, Trappe S. Resistance exercise, skeletal muscle FOXO3A, and 85-year-old women. J. Gerontol. Ser. A Biol. Sci. Med. Sci. 2010; 65(4):335-343. doi: 10.1093/gerona/glq005. [PubMed: 20139145]

108. Konopka AR, Douglass MD, Kaminsky LA, Jemiolo B, Trappe TA, Trappe S, Harber MP. Molecular adaptations to aerobic exercise training in skeletal muscle of older women. J. Gerontol. Ser. A Biol. Sci. Med. Sci. 2010; 65(11):1201-1207. doi:10.1093/gerona/glq109. [PubMed: 20566734]

109. Konopka AR, Trappe TA, Jemiolo B, Trappe SW, Harber MP. Myosin heavy chain plasticity in aging skeletal muscle with aerobic exercise training. J. Gerontol. Ser. A Biol. Sci. Med. Sci. 2011; 66(8):835-841. doi:10.1093/gerona/glr088. [PubMed: 21659340]

110. Bennell KL, Hinman RS. A review of the clinical evidence for exercise in osteoarthritis of the hip and knee. J. Sci. Med. Sport. 2011; 14(1):4-9. doi:10.1016/j.jsams.2010.08.002. [PubMed: 20851051]

111. Williams MA, Haskell WL, Ades PA, Amsterdam EA, Bittner V, Franklin BA, Gulanick M, Laing ST, Stewart KJ. Resistance exercise in individuals with and without cardiovascular disease: 2007 update: a scientific statement from the American Heart Association Council on Clinical Cardiology and Council on Nutrition, Physical Activity, and Metabolism. Circulation. 2007; 116(5):572-584. doi:10.1161/CIRCULATIONAHA.107.185214. [PubMed: 17638929]

112. Butterfield GE, Thompson J, Rennie MJ, Marcus R, Hintz RL, Hoffman AR. Effect of rhGH and rhIGF-I treatment on protein utilization in elderly women. Am. J. Physiol. 1997; 272(1 Pt 1):E94-E99. [PubMed: 9038857]

113. Lebrasseur N, Schelhorn T, Bernardo B, Cosgrove P, Loria P, Brown T. Myostatin inhibition enhances the effects of exercise on performance and metabolic outcomes in aged mice. J. Gerontol. Ser. A Biol. Sci. Med. Sci. 2009 doi:10.1093/gerona/glp068.

114. Murphy KT, Koopman R, Naim T, Léger B, Trieu J, Ibebunjo C, Lynch GS. Antibody-directed myostatin inhibition in 21-mo-old mice reveals novel roles for myostatin signaling in skeletal muscle structure and function. FASEB J. 2010; 24(11):4433-4442. doi:10.1096/fj.10-159608. [PubMed: 20624929]

115. Cohn RD, van Erp C, Habashi JP, Soleimani AA, Klein EC, Lisi MT, Gamradt M, ap Rhys CM, Holm TM, Loeys BL, Ramirez F, Judge DP, Ward CW, Dietz HC. Angiotensin II type 1 receptor blockade attenuates TGF-beta-induced failure of muscle regeneration in multiple myopathic states. Nat. Med. 2007; 13(2):204-210. doi:10.1038/nm1536. [PubMed: 17237794]

116. Burks TN, Andres-Mateos E, Marx R, Mejias R, van Erp C, Simmers JL, Walston JD, Ward CW, Cohn RD. Losartan restores skeletal muscle remodeling and protects against disuse atrophy in sarcopenia. Sci. Transl. Med. 2011; 3(82):82ra37. doi:10.1126/scitranslmed.3002227. 


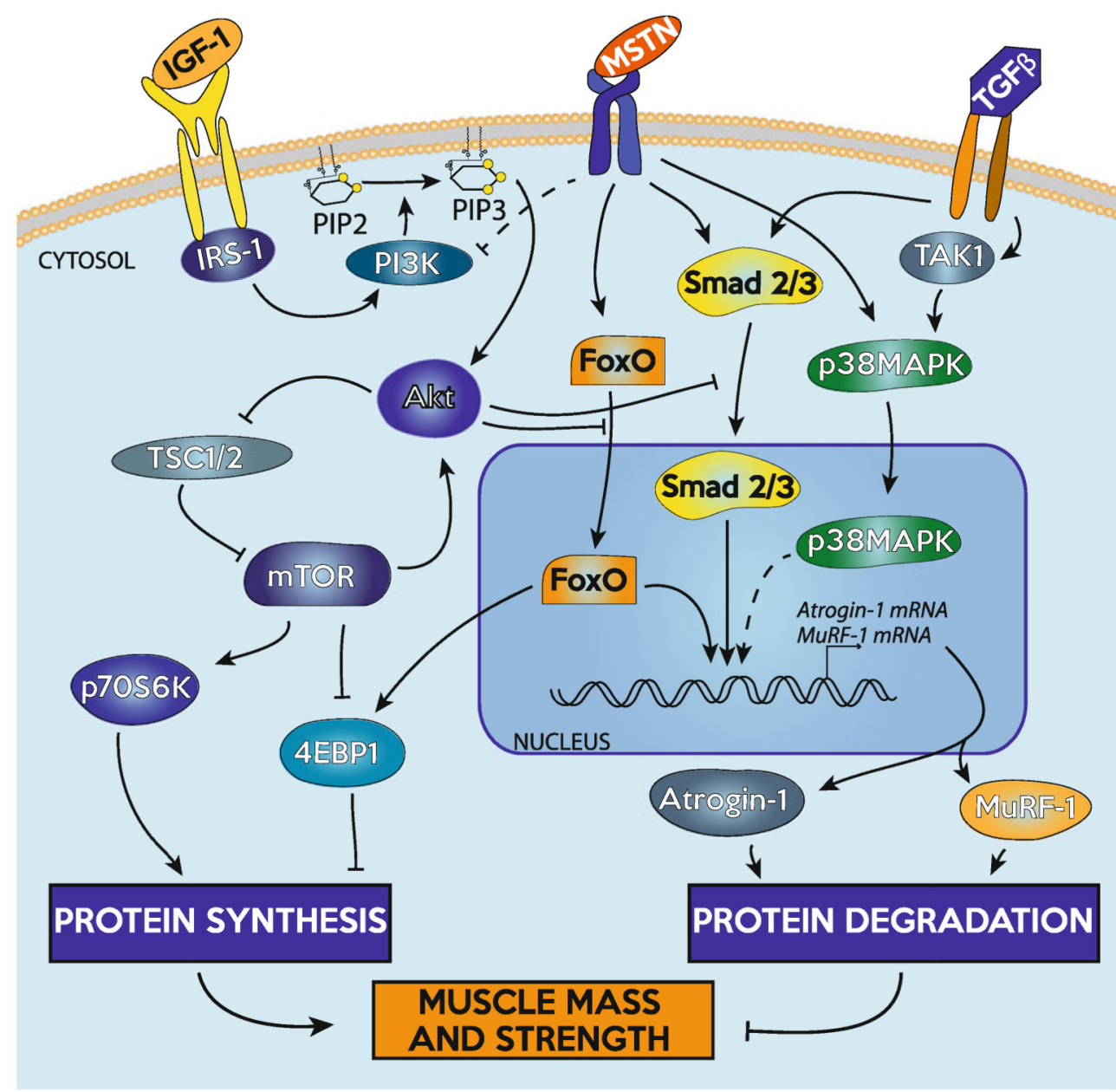

Fig. 1.

Overview of selected signaling pathways discussed in this review as they relate to the regulation of skeletal muscle mass 